\section{New Estonian records: Mosses}

\section{Kai Vellak ${ }^{1}$, Leiti Kannukene ${ }^{2}$, Mare Leis ${ }^{3}$ \& Nele Ingerpuu ${ }^{1}$}

\author{
${ }^{1}$ University of Tartu, Institute of Ecology and Earth \\ Sciences, 40 Lai Street, Tartu 51005, Estonia. \\ E-mail: kai.vellak@ut.ee \\ ${ }^{2}$ Estonian Museum of Natural History, 29A Lai Street, \\ Tallinn 10133, Estonia. \\ ${ }^{3}$ Estonian University of Life Sciences, Institute of \\ Agricultural and Environmental Sciences, 181 Riia Street, \\ Tartu 51014, Estonia.
}

The number of bryophyte species known from Estonia was 583 in 2011 (Vellak et al., 2011). Seven moss species and one subspecies have been identified and added as new to the Estonian bryoflora during last two years. The specimens are deposited in the bryological herbaria of the Natural History Museum, University of Tartu (TU), University of Life Sciences (TAA) and Estonian Museum of Natural History (TAM). We can conclude that the list of Estonian bryoflora includes now 590 species (http://www.botany. ut.ee/bruoloogia/).

ATRICHUM CRISPUM (James.) Sull. [pehme kadrisammal]

1 st loc.: Valga Co., Õru District, Lata village, paludified forest, in a sandy pit $\left(58^{\circ} 57^{\prime} \mathrm{N}\right.$ $\left.26^{\circ} 13^{\prime} \mathrm{E}\right)$, leg. M. Leis, 10 Sep 2004 , det. M. Leis, 8 Feb 2012; (TU 157121). Since the first find in 2004, eight more localities have been found from different regions in Estonia checking all Atrichum tenellum specimens kept in three herbaria of Estonia (TAA, TAM and TU). Therefore, having already nine localities in Estonia, its frequency class can be estimated as rather rare (st r).

This species grows on moist sandy soil in old boreal coniferous and mixed forests. It is widely distributed in North America, locally abundant in Britain and Ireland (Frey et al., 2006), but not known from Scandinavia and other Baltic states.

BRYUM KUNZEI Hornsch. [Kunze pungsammal] 1 st loc.: Hiiu Co., Pühalepa District, Hiiumaa Islets' Protection Area, northern coast of the Islet Palgirahu, on a coastal ridge $\left(58^{\circ} 49^{\prime} \mathrm{N}\right.$ $\left.22^{\circ} 59^{\prime} \mathrm{E}\right)$, leg. L. Kannukene, 27 July 2001, det. L. Kannukene, Jan 2013 (TAM B783:133; TAM B783:134).
This species has been treated earlier as a variety of $B$. caespiticium Hedw., but recently has been acknowledged as a separate species (Holyoak, 2004). B. caespiticium is rather common in different meadow communities, whereas $B$. kunzei occurs on basic substrates in open habitats (Hallingbäck et al., 2008). Its distribution extends from South Europe to South Scandinavia (Frey et al., 2006).

GRImmia ANOMALA Hampe ex Schimp. [kivirahnik] 1 st loc.: Harju Co., Paldiski City Administration, Suur-Pakri Island, moist alvar meadow, on shaded big erratic boulder, in crevices $\left(59^{\circ} 20^{\prime} \mathrm{N}\right.$ $\left.23^{\circ} 53^{\prime} \mathrm{E}\right)$, leg. L. Kannukene, 17 June 1994, det. L. Kannukene, 11 March 2013 (TAM B872:60). This species is distributed in mountain regions of Europe, from Scandinavia to Spain, also in North America and Asia, being rare throughout its distribution area (Ignatova \& Muños, 2004). Grows preferably on siliceous cliffs and boulders in half-shaded to exposed areas (Hallingbäck et al., 2006).

Microbryum Starckeanum (Hedw.) R. H. Zander [Starke pisisammal]

1 st loc.: Saare Co., Kihelkonna District, Vilsandi Nature Park, Vesiloo Island, on soil of periodically wet alvar meadow $\left(58^{\circ} 23^{\prime} \mathrm{N} 21^{\circ} 49^{\prime} \mathrm{E}\right)$, leg. L. Kannukene, 27 May 1978, det. O.M. Afonina as Pottia mutica Vent., 29 Apr 1982, ver. L. Kannukene, February 2013 (TALL D010208); 2 nd loc.: Harju Co., Saue District, $0.5 \mathrm{~km}$ WSW from Rahula village, on moist alvar meadow

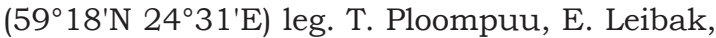
20 Oct 2000, det. L. Kannukene, 25 Feb 2013 (TU 158174); 3 rd loc.: Harju Co., Harku District, Türisalu Cliff, on alvar meadow together with Ditrichum flexicaule and Encalypta rhabtocarpa

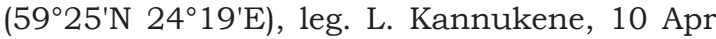
2001, det. L. Kannukene, 25 Feb 2013 (TAM B796:230).

Specimens identified now as $M$. starckeanum have been identified earlier as Pottia mutica Vent. or Pottia davalliana (Sm.) C. E. O. Jensen (Ros et al., 1996). From 11 specimens named as $P$. davalliana and kept in Estonian herbaria (TAA, TAM, TU), three specimens were verified to be Microbryum starkeanum and eight remained as Microbryum davallianum (Sm.) R. H. Zander (syn. $P$. davalliana). The first species is very rare and the second is rather rare in Estonia according to the known herbaria data. Both species 
occur on exposed calcareous periodically wet clayey soil (Hallingbäck et al., 2008).

ThAmnobryum NeCKeroides (Hook.) E. Lawton [tömp-põõsassammal]

1 st loc.: Saare Co., Valjala District, Kaali Meteoritic Crater, on a shaded limestone $\left(58^{\circ} 22^{\prime} \mathrm{N}\right.$ $\left.22^{\circ} 40^{\prime} \mathrm{E}\right)$, leg. L. Kannukene, 26 May 1977, det. K. Vellak, M. Leis, 8 Feb 2012 (TAM B753:43).

$T$. neckeroides grows both on basic and acid substrates, sometimes also on tree bases and is recorded in Europe rather recently from Czech Republic, Germany and Italy (Mastracci, 2003) and from Latvia (Ābolina et al., 2011). It has wider distribution area as was known earlier, being distributed on both hemispheres (Mastracci, 2003).

Thamnobryum SUbSERRATUm (Hook. ex Harv.) Nag. $\& Z$. Iwats. [sarnas-põõsassammal]

1 st loc.: Viljandi Co., Pärsti District, Õisu, on a stone in Ôisu River. (58 $\left.16^{\prime} \mathrm{N} 25^{\circ} 36^{\prime} \mathrm{E}\right)$, leg. M. Leis, 17 June 1996, det. K. Vellak, N. Ingerpuu, M. Leis, 5 Feb 2012 (TU 167926).

This species has ecological demands similar to T. alopecurum (Hedw.) Gangulee, and it grows on wet riverbanks in half shade (Frahm, 2009).

SPhagnum MaJus (Russow) C.E.O. Jensen subsp. NORVEGICUM

1 st loc.: Lääne-Viru Co., Kuusalu District, Lahemaa National Park, Viru bog, on the bank of a bog pool $\left(58^{\circ} 34^{\prime} \mathrm{N} 26^{\circ} 10^{\prime} \mathrm{E}\right)$, leg. K. Vellak 18 Aug 2012, det. K. I. Flatberg 18 Aug 2012 (TU 168616).

This subspecies is characterized by paler color and stronger habitus comparing with the subspecies majus. This moss is known from Scandinavia and North America, grows in ombrotrophic and minerotrophic lowland habitats, preferably in carpets (Flatberg, 1987).

ZYGODON RUPESTRIS Schimp. ex Lorentz [kaljukrussik]

1 st loc.: Jõgeva Co., Palamuse District, Luua Manor Park, on the trunk of a deciduous tree (5839'N 26³6'E). July 2012, leg. I. Jürjendal, det. I. Jürjendal, K. Vellak, N. Ingerpuu, Nov 2012 (TU 168692).

This species has been known under different names and on different taxon levels since 1865, the present name has been acknowledged quite recently (Karttunen, 1984). This moss is common in southern part of Europe, growing mainly on trunks of deciduous trees and on rocks in oceanic regions (Smith, 2004).

\section{ACKNOWLEDGEMENTS}

Dr. Blanka Shaw is thanked for verifying specimens of Atrichum crispum. The work has been financed by Estonian Ministry of Education and Research (SF0180012s09, SF0180095s08, SF0170052s08, RP1LMBOTK).

\section{REFERENCES}

Ābolin,a, A.A., Reriha, I.S., Opmanis, A.G., Suško, U.A., Ignatova, E.A. 2011. New and rare moss records from Latvia 1. Arctoa 20: 265-266.

Flatberg, K.I. 1987. Taxonomy of Sphagnum majus (Russ.) C. Jens. Det Kongelige Norske Videnskabers Selskab. Skrifter 2: 1-42.

Frahm, J.-P. 2009. Zur Unternscheidung von Thamnobryum subserratum (Hook. ex Harv.) Nog. \& Z . Iwatz. und Thamnobryum neckeroides (Hook.) E. Lawton. Archive for Bryology 39: 1-7.

Frey, W., Frahm, J.-P., Fischer, E., Lobin, W. 2006. The liverworts, mosses and ferns of Europe. Heidelberg, Gustav Fischer Verlag.

Hallingbäck, T., Lönell, N., Weinbull, H., Hedenäs, L, von Knorring, P. 2006. Nationalnyckeln till Sveriges flora och fauna. Bladmossor: Sköldmossor - blàmossor. Bryophyta: Buxbaumia-Leucobryum. ArtDatabanken, SLU, Uppsala.

Hallingbäck, T., Lönnell, N., Weinbull, H., von Knorring, P., Korotynska, M., Reisborg, C., Birgersson, M. 2008. Nationalnyckeln till Sveriges flora och fauna. Bladmossor: Kompaktmossor-kapmossor. Bryophyta: Anoectangium-Orthodontium. ArtDatabanken, SLU, Uppsala.

Holyoak, D.T. 2004. Taxonomic notes on some European species of Bryum (Bryopsida, Bryaceae). Journal of Bryology 26(4): 247-264. http:/ / dx.doi. org/10.1179/174328204X19423

Ignatova E., Muños J. 2004. The genus Grimmia Hedw. (Grimmiaceae, Musci) in Russia. Arctoa 13: $101-182$.

Karttunen, K. 1984. Zygodon gracilis, Z. rupestris and $Z$. dentatus, comb nova (Musci, Orthotrichaceae). History and nomenclature. Annales Botanici Fennici 21(4): 343-348.

Mastracci, M. 2003. Thamnobryum neckeroides (Bryopsida: Neckeraceae): lectotypification, synonymies, diagnostic characters, habitat and distribution. Journal of Bryology 25: 115-120. http:/ / dx.doi.org/10.1179/037366803235001788

Ros, R.M., Guerra, J.S., Carrion, J.S., Cano, M.J. 1996. A new point of view on the taxonomy of Pottia starckeana agg. (Musci, Pottiaceae). Plant systematics and Evolution 199: 153-165. http:/ / dx.doi.org/ 10.1007/BF00984902

Smith, A. J. E. 2004. The moss flora of Britain and Ireland. Cambridge University Press. http://dx.doi. org/ 10.1017/CBO9780511541858

Vellak, K., Leis, M., Ingerpuu, N., Kannukene, L. 2011. New Estonian records: mosses. Folia Cryptogamica Estonica 48: 153-154. 